\title{
Immigrant Entrepreneurship in Post-Socialist Countries of the European Union: Motives and Patterns of Entrepreneurship of Post- Soviet Immigrants in Hungary
}

DOI: https://doi.org/10.11567/met.33.1.3 UDK: 658.012-054.62(47+57:439)"1991/2016" Izvorni znanstvenih rad Primljeno: 30.11.2016. Prihvaćeno: 10.07.2017.

Sanja Tepavcevic

Budapest Business School - Eötvös Loránd University, Budapest sanja.tepavcevic@gmail.com

\begin{abstract}
SUMMARY
This paper explores the relationship between migration, entrepreneurship, and foreign direct investments by focusing on entrepreneurial activities of post-Soviet (im)migrants in Hungary in periods between 1991 and 2016. Post-Soviet migrants are in focus because between 1956 and 1989 the Soviet Union coercively kept Hungary in the Socialist bloc. Based on surveys and in-depth interviews, this paper reveals that there are considerable differences in patterns of entrepreneurship among postSoviet immigrant entrepreneurs depending mostly on time of their arrival to Hungary. Similarly, motives for entrepreneurship among the first-wave migrants combine negative factors in the former Soviet Union with positive factors encountered in Hungary, while factors in Hungary recognized as positive by most post-Soviets prevail in motives for later waves of post-Soviet migration and entrepreneurship in Hungary. The paper also demonstrates that many relatively small investments have been conducted since 2000 by citizens of post-Soviet countries to Hungary. Some of them are transforming into an entrepreneurial activity, serving also as a basis for immigration to Hungary.
\end{abstract}

KEY WORDS: immigrant entrepreneurship, Post-Soviet immigrants, Hungary, foreign direct investment (FDI), post-socialist Europe

\section{INTRODUCTION}

Immigrant entrepreneurship has been attracting scholars' attention over the last two decades because it became one of the most visible processes of globalization. As Rath (2006: 1) points out "immigrants from less-developed countries moved to advanced economies, embodying the complex process of globalization in a very palpable sense [...] They start businesses 
in their countries of settlement and become 'self-employed' or 'immigrant entrepreneurs"'.

Indeed, immigrants from low-to-middle income economies (according to International Monetary Fund - IMF (2016), with Gross Domestic Product per capita - GDP-PPP below $\$ 35,000$ ) to high income economies (according to IMF (2016), with GDP-PPP between $\$ 35,000$ and $\$ 50,000$ that have usually been defined in the literature as "advanced economies") and their entrepreneurship have been widely spread phenomena. As such, they have been frequently the focus of research in social sciences.

For instance, Piore's (1979) "dual labour market" theory explains that high income economies are segmented into capital-intensive primary sector, and labour-intensive secondary sector. According to Piore (1979), regarding the demand side, primary jobs appeared with the growth of corporate capitalism, while secondary market positions persisted. On the supply side, Piore suggests, primary market workers emerged with increased unionizations while secondary labourers are constantly being recruited. While Piore's study focuses on patterns of integration of immigrant workers into labour markets of receiving countries, more recent studies reveal that a number of immigrants from countries with low-to-middle income immigrate to countries with high income with considerable savings. By investing these savings into small or medium businesses, these migrants receive resident permits for them and their families (Rath, 2006). This observation highlights a significance of motives for immigrant entrepreneurship and the role of foreign direct investment (FDI) in it.

At the same time, search for better working conditions and payment than in the country of origin have been among top motives for migration, which in many cases led to a frequent commutation between home and host countries (Basch, Glick Schiller and Szanton Blanc, 1994). On the other hand, once reaching a high income country, immigrants from the countries with low-to-middle income have frequently faced limited access to a host country's labour market. Thus, Light (1984) points out that this disadvantage in the labour market of a host country and immigrant groups' values are among most important motives that encourage immigrants' business enterprise. He also underlines that in many instances entrepreneurship has been the only option for immigrants to generate income in a host country. Along with Light, other scholars of immigrant entrepreneurship have so far analyzed motives, sources of immigrant entrepreneurship, dynamics within and among the various immigrant groups mostly in traditional immigrant countries, such as the United States (US) of the 1970s and European 
countries in the late 1980s (Rath, Eurofound, 2011), and the impact of immigrant entrepreneurs on economies of sending and receiving countries, usually found to be positive for both (Kugler and Rapoport, 2011).

Simultaneously, with certain exceptions, very little attention has been devoted to immigrant entrepreneurship beyond the traditional immigrant countries. As Marchand and Siegel (2014: 4) justly point out, this is due to the fact that "the literature on immigrant entrepreneurship is focused on the situation in developed countries", thus it is "close to no evidence written on the topic" concerning a situation beyond high income economies of the Western Europe, United States, Canada Australia and recently Singapore and South Korea. Indeed, apart from Brzozowski and Pedziwiatr (2016), who addressing immigrant entrepreneurship in Lesser Poland find that it operates mainly at the mainstream market, studies of immigrant entrepreneurship in post-socialist Europe are absent. As UN statistics on migration demonstrate, countries with middle income economies, especially post-socialist ones, have increasingly became hosts to almost as many immigrants as have had traditional advanced economies (UN, 2015). This poses a puzzling question: Why do people from one middle-income post-socialist country choose to move to another middle-income post-socialist country? Another related intriguing question addressed in this paper is to what extent FDI provides sources for immigrant entrepreneurship?

In order to answer these questions and produce a new knowledge about immigrant entrepreneurship in post-socialist countries, current members of the European Union (EU), this paper focuses on entrepreneurial activities of post-Soviet diaspora in Hungary. Post-Soviet migrants are in focus because between 1956 and 1989 the Soviet Union coercively kept Hungary in the Socialist bloc. The concept of post-Soviet migrants appeared in early aftermath of the dissolution of the Soviet Union to refer to former Soviet citizens, usually native-Russian speakers. The concept has been problematized to a large extent due to the fact that after dissolution about 25 million Russians remained outside the borders of the Russian Federation overnight. National identity among post-Soviet citizens, both in their self-perception and with regard to citizenship, is usually highly contested: some of them have double post-Soviet citizenships (e.g. Ukrainian and Russian), but consider themselves Russians. Other Russian-native speakers acquired Hungarian citizenship, but still consider themselves Russians/Ukraininans/Ruthenians, while there are also significant number of ethnic Hungarians originating from former Soviet republics, and having dual post-Soviet - Hungarian citizenship. 
In the present paper, the concept of post-Soviet (im)migrants refers to all former Soviets, who were born in countries-remnants of the former Soviet Union, and whose native language is Russian, or are bilingual. The term entrepreneurship is defined as "the capacity and willingness to develop, organize and manage a business venture along with any of its risks in order to make a profit" (Business Dictionary). ${ }^{1}$ Immigrant entrepreneur here refers to foreign-born, self-employed officially registered person, regardless of whether s/he acquired Hungarian citizenship. The terms place or country of origin, sending country, and home country are used in this paper as synonyms and interchangeably. The terms place or country of destination, receiving country, and host country are also used as synonyms.

The paper demonstrates that motives for entrepreneurship among the first-wave (im)migrants combine negative factors in the republics-remnants of the former Soviet Union with positive factors encountered in Hungary, while factors in Hungary recognized as positive by most post-Soviets prevail in motives for later waves of post-Soviet migration and entrepreneurship in Hungary. The paper also reveals that many relatively small investments have been conducted since 2000 by citizens of post-Soviet countries to Hungary to be transformed into an entrepreneurial activity and as such to serve as a basis to reside in Hungary.

The remainder of the paper proceeds as follows. The next section describes Lee's (1966) theoretical framework developed for the study of motives for migration and adapts it for the exploration of motives for conducting immigrant entrepreneurship. The existing literature on immigrant entrepreneurship is also systematized according to this analytical framework. The following section describes the research strategy of obtaining and gathering the data about post-Soviet entrepreneurs in Hungary. The empirical section traces emergence of the post-Soviets in Hungary and motives for their entrepreneurship, and the role of FDI in this entrepreneurship. The findings are discussed and situated into the existing literature in the final section.

http://www.businessdictionary.com/definition/entrepreneurship.html 


\section{MOTIVES AND PATTERNS OF MIGRATION AND OF IMMIGRANT ENTREPRENEURSHIP:FRAMEWORK FOR THE ANALYSIS}

In analysing motives for migration from the former Soviet Union to Hungary, the present paper builds upon Lee's (1966) framework, based on four major groups of factors that shape motives for migration and volumes of migration: 1) factors associated with the area of origin, i.e. with home/ sending country; 2) factors associated with the area of destination, i.e. with host/receiving country. These groups of factors are graphically presented in Figure 1 below in boxes 1 and 2 respectively. In this context and with regard to business cycles, Lee (1966: 53) points out that "during periods of economic expansion [...] the contrast between the positive factors at origin and destination is [...] heightened, and the negative factors at origin seem more distressing". Thus, it is useful to take into consideration this proposition in the exploration of motives for immigrant entrepreneurship.

Lee also justly points out that factors influencing decisions related to migration can be positive and negative in both home and host countries (presented as + and - in boxes 1 and 2 in Figure 1). Therefore, he also outlines another two groups of factors influencing decisions related to migration, namely: 3) intervening obstacles, such as migration-restricting laws and physical barriers, and; 4) personal factors, such as life cycle-related interests, or change of marital status. These two additional groups of factors influencing migration-related decision making is graphically presented in Figure 1 as boxes 3 and 4 . Lee also keenly notices that the same factors related to home and host countries can be seen as positive, negative or insignificant, depending on individual circumstances grouped under personal factors (possible combinations among groups of factors, thus, are marked by arrows in Figure 1).

In this way, the present analytical model sets the criteria to evaluate motives for immigrant entrepreneurship proposed by the existing academic literature. Starting from box 1 (lower right corner), negative factors in a place of origin that are most frequently analysed by the literature are migration caused by war (war refugees) and for political reasons that prompt search for political asylum (see, for example, Halilovich, 2011). Within this group of factors is also dissatisfaction with economic situation, which prompts general search for a better life standard (Wilson and Portes, 1980; UN, 2015). 
Figure 1. Model for the analysis of motives for immigrant entrepreneurship

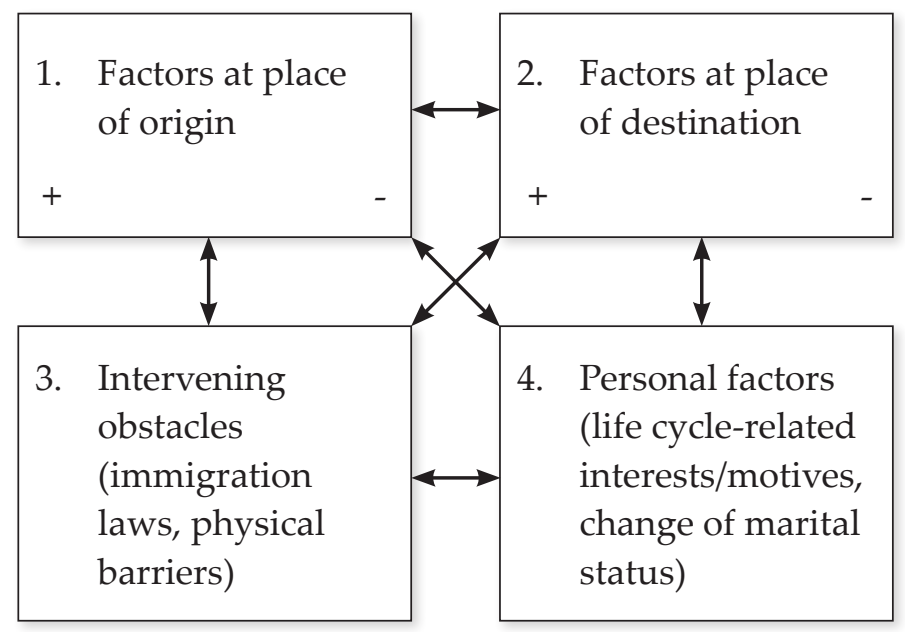

Source: Lee (1966), adapted by the author

Many scholars of immigrant entrepreneurship recognize that negative factors at a place of origin are usually combined with positive factors related to a place of destination (Figure 1, box 2 lower left corner). For instance, Portes (1997) and Waldinger (2009) point towards getting better payment for the same job and better career/professional opportunities than available in home countries, while Graham (2013) highlights possibilities for getting support for the development of innovations as driving motives from lowto-middle income countries to those with high income. Simultaneously, among positive factors related to a place of destination are demand from an ethnic community for certain ethnic products and/or services (Orozco, 2008), and investment opportunities in host countries (Marchand and Siegel, 2014). Therefore, those immigrants who had come with significant savings have usually been engaged in one or other form of an ethnic enterprise, since in it they have had certain competitive advantages in comparison to native population (Light, 1984). One of the recent examples of such advantage is Byford's (2012) study of entrepreneurship of Russian diaspora in Great Britain: addressing the relationship between the Russian state and Russian diaspora in Great Britain, Byford (2012) demonstrates that Russianspeaking diaspora to a large extent uses Russian culture-promoting "Compatriots" project organized by the Russian state to enhance entrepreneurial activity, and consequently, to gain profits. 
This is not surprising given that, when coming to a host country, many immigrants face limited access to a host country's labour market due to structural, statistical and sometimes even taste discriminations (Zhou, 2004; Marchand and Siegel, 2014). As Light (1984) demonstrated and Brixy, Sternberg and Vorderwülbecke (2013) confirmed, in such cases entrepreneurship provides the only possibility for an income to immigrants. Similarly, Deakins et al. (2007) and Lassalle, Hughes and Helinska-Hughes (2011) find that immigrant entrepreneurship usually relies on informal sources due to lack of knowledge about start-up funding in a host country. All of these refer to negative factors related to place of destination (Figure 1, box 2 lower right corner) prompting immigrant entrepreneurship.

As Rath (2006) points out, for those immigrants, who had represented upper middle class in their low-to-middle income home countries and came to high income host countries with significant capital savings, entrepreneurship has been a way to obtain residence for them and their families in host countries. This Rath's finding underlines the significance of usually restricting immigration laws, which Lee (1966) grouped under intervening obstacles (Figure 1, box 3) in accessing/residing in a country of destination. This can be attached also as a negative factor related to a place of destination that prompts immigrant entrepreneurship.

At the same time, this Rath's (2006) finding also reveals a close connection between intervening obstacles and personal factors, such as familyrelated issues influencing immigrant entrepreneurship. Therefore, in addressing second research question that this paper aims to answer, namely to what extent FDI provides sources for immigrant entrepreneurship, it is important to look at possible incentives to invest in order to receive a residence permit in a country of destination. All these groups of factors serve in this paper the in-depth exploration of motives and patterns of immigrant entrepreneurship of the post-Soviet entrepreneurs in Hungary. The following section explains in detail the ways how the data on it has been obtained.

\section{DESCRIPTION OF THE RESEARCH STRATEGY}

The data were collected in the periods between 2010 and 2016 in three distinct phases. In the first phase, statistical information about the numbers of post-Soviet immigrants in Hungary was collected from annual reports of the Hungarian Migration Office. Since the information of the companies' owners is not available as an open source, information about post-Soviet entrepreneurs has been collected from the Russian-language websites about 
Hungary and via informal personal communication with representatives of the Russian diaspora in Hungary. In the second phase, those post-Soviet entrepreneurs, whose contacts were obtained during the first phase of research, were directly surveyed by a semi-structured questionnaire. This questionnaire included the following questions:

- What was the reason/motivation for leaving your country of origin?

- What was the reason/motivation for migrating to Hungary?

- What was the reason for becoming an entrepreneur in Hungary?

- What were financial sources for starting your enterprise?

In this phase, I surveyed 10 post-Soviet entrepreneurs in Hungary. Some of them were accidental (for example, the conversation with shoe designer Anna Zuboeva in her showroom on Wesselenyi utca in Budapest, in the fall of 2010). Seven of these 10 post-Soviet entrepreneurs shared contacts with some of their acquaintances, who are also post-Soviet entrepreneurs in Hungary. As a result, the number of surveyed post-Soviet entrepreneurs reached 30. Data collected in this phase of research revealed that most post-Soviet entrepreneurs were reluctant to talk openly about the financial sources to establish their businesses and/or to pursue self-employment in Hungary. Thus, in the last phase of research the questions that formed the basis for in-depth interviews were formulated in a way to neutralize these inconveniences, and to allow for open-ended answers. For example:

- Did you apply / have you used any grants / have you participated in any programs for start-up, or for small business available in Hungary?

- Were such programs available when you arrived to Hungary at all?

- What difficulties did you face, if any, founding and conducting business in Hungary?

Responses have evolved around the following variants of answers: a) invested own savings earned in Hungary; $b$ ) invested own savings earned in a country of origin/elsewhere; c) used collaboration with (in)formal investors.

Given that many questions have been ethically sensitive, two preventive measures were taken to address this problem: first, respondents were recruited on a purely voluntary basis. Second, when required, their names were replaced by approximate description of their positions. As I mentioned above, 30 entrepreneurs (approximately one third of them obtained 
Hungarian citizenship, apart from their original post-Soviet one) and their acquaintances were surveyed. Fifteen of them were available for in-depth interviews. Thirteen most illustrative ones have been directly cited in this paper. Only 8 of these 13 agreed on a formal electronically recorded interview. Other four shared their experiences during personal communication while I was taking the notes. Therefore, in further text, when citing electronically recorded interviews, I refer to them as "personal interviews", while to the notes that included exact sentences that I was writing down as an interviewee was talking, I refer as "personal communication". All surveys were conducted in Russian, electronically systematized according to the answers and translated into English. All interviews were conducted in Russian, electronically transcribed, and translated into English.

There were also three cases of significant post-Soviet entrepreneurs, whose businesses were worthy to address in this paper, but entrepreneurs were not directly available for interviews. In these cases, where it was available, I utilized interviews with these entrepreneurs published by Hungarian and Russian-language media in Hungary, and discussing issues closely related to one or both research questions addressed in this paper. Used parts of these interviews were translated into English. When, however, even such information was not available, I interviewed at least one of knowledgeable acquaintance of these entrepreneurs. Finally, the data received was systematized and analysed within the framework adapted from Lee (1966), thus, in the way to answer research questions.

\section{POST-SOVIET ENTREPRENEURSHIP IN HUNGARY}

Among former Soviets, Russians and Armenians have historically been present in Hungary, whether through monarchical marriages and trade starting from the eleventh century or as occupying troops in the second half of the twentieth century. After the Second World War about 60,000 of Southern Soviet troops were located in various places across Hungary, with largest communities located in Budapest, Paks and Debrecen. They organized hospitals, schools, clubs, and shops, where officers' spouses were working (Molodikova, 2014) to fulfil its own needs, so their livelihood activities were community-based and community-self-sustaining.

With the demise of the Soviet Union, the Southern Soviet troops were disbanded, but some of their remnants stayed in Hungary, especially those who provided procurement services to the Soviet army. These remnants happened to be first post-Soviet entrepreneurs in Hungary, as they used 
their existing connections and experience to sustain their livelihood after the Soviet system collapsed (former communications expert of the Hungarian trade office, personal interview, April 18, 2016). In words of a former Soviet soldier, the collapse of the Soviet Union closed the way back "home" to those representatives of the Southern Soviet troops, who were ethnical Russians from other Soviet republics.

Before coming to Hungary as a part of the Soviet troops, I worked for the Soviet Army in Moldova. When the Union collapsed, me and my family were in Hungary, and there was nothing in Moldova that I could do to sustain our livelihood. We used existing contacts with Hungarians to receive a citizenship, so we stayed here and organized small business in logistics. (personal communication, January 31, 2013)

Therefore, as this quotation suggests, temporary work-related relocation from the Soviet Union to Hungary became permanent residence. Thus, this seems to refer mostly to the negative factors related to the place of origin in favour to stay in place of destination. In this particular case, these were the collapse of the Soviet Union and related economic and ethnic tensions in its former republics.

Since the beginning of transition from planned to market economy Hungary and the former Soviet countries have developed in very different ways. While Hungary adopted democratic constitution and joined Western political and military institutions such as the European Union and NATO, most of post-Soviet republics have increasingly kept most of authoritarian elements in their political systems, while Russia has also re-created its zone of influence among some of the former Soviet states. To a certain extent, this made Hungary generally more attractive place of living for the citizens of post-Soviet republics, than their respective countries of origin. Simultaneously with these political and economic transformations, all post-socialist countries have gradually changed their migration policies, so did Hungary. While most migrants in Hungary during the Cold War were students from other countries of the socialist bloc based on mutual agreements among then socialist countries (Janka et al., 2007), post-1989 migrations from other post-socialist countries were prompted by visa-free regime, which existed up until 2003, a year before Hungary joined the EU (Molodikova, 2014).

The Hungarian Central Statistical Office (KSH) reported that on January 1, 2015 the number of Ukrainian citizens was 6906, making them the second largest group of migrants in Hungary after Romanians, while most of the labour and circular migrants from Ukraine came from Transcarpathia, usu- 
ally from Beregovo/Beregszasz, which is a Hungarian minority area (Kósa, 2015). KSH also reported that the official number of Russian citizens in Hungary in 2014 was about 4000. According to the representative of the Russian Embassy in Budapest, this number includes representatives of the Russian Embassy and Trade Representative Office in Hungary, representatives of Russian companies, and Russian citizens, who work in multinational (other than post-Soviet) companies in Hungary (personal communication, March 2, 2012). The Hungarian Migration Office also reported that the other 2000 Russian citizens received Hungarian citizenship (Molodikova, 2014). Nevertheless, the number of post-Soviet citizens in Hungary seems to be much larger. According to Rita Hasanova, a founder and owner of "Alfavit" Budapest-based center for study of Russian language, currently there are about 10,000 native Russian speakers, former Soviet citizens who live in Hungary (personal interview, October 7, 2016).

The fact that Hungarian first state TV channel M1 launched news broadcasting in Russian language ${ }^{2}$ serves a proof that post-Soviet - mostly Russian-speaking - immigrants have become a significant language group in Hungary. Another more interesting fact from the same source is that Russian community in Hungary plans to apply for a recognition of the minority status in Hungary. Still, post-Soviet community in Hungary is a very diverse group in terms of place of origin, time of arriving to Hungary, social stratification and occupation (Molodikova, 2014). Its cultural integration into Hungarian society also varies along the aforementioned lines, which affects their livelihood/economic activities to a different extent. As a result, approximately one third of livelihood activities of post-Soviet diaspora in Hungary are related to entrepreneurship, either through the ownership of small or medium businesses, or through an employment in these businesses. These businesses are often concentrated in Budapest and they include: six post-Soviet-owned tourism agencies, three media outlets (one newspaper and two websites), four restaurants, two real-estate companies, two construction companies, two retail shop chains and three foundations that promote Russian culture. Thus, as the following subsections demonstrate, most of these businesses either serve the Russian-speaking community in Hungary, or are based on close contacts with the country of origin. There are also certain exceptions among the new waves of post-Soviet immigrant entrepreneurship.

See: Rossiya 24 “Vengerskoe televidenie: teper' I na russkom”, Vesti, December 6, 2015, http://www.vesti.ru/doc.html?id=2694954 


\subsection{From representatives of the Soviet companies to immigrant entrepreneurs}

I do not perceive myself as migrant, and I cannot say that I planned to migrate, and that I chose to come to Hungary on purpose to move here. [...] After my studies in Hungary I came back to Moscow and I worked and lived there for almost 10 years. Then there was a vacancy of a representative of Intourist in Hungary. [...] As I knew the country and the language, they sent me here. [...] It was planned as 3-4 years-long business trip, but, as you see, that business trip lasts for almost thirty years. (Russian owner of tourism agency in $\mathrm{Bu}-$ dapest; personal interview, October 19, 2016)

As the quote above demonstrates, some of the current post-Soviet entrepreneurs in Hungary have never thought neither of emigration from their home countries, nor of becoming entrepreneurs. According to Rita Hasanova, she and her family became immigrants in Hungary as a result of the dissolution of the Soviet Union and its companies that were all state-owned.

I came here to do my PhD in chemistry... Later my husband and I worked for the Soviet-Hungarian joint company "Energotechna" in 1989. We didn't plan to move here at all, nobody ever thought to stay in Hungary, or did an effort to escape from the USSR. There was a perestroika there in Russia and here in Hungary as well, and everything fell apart, and our institute also was bankrupt because nobody supported it. [...] We decided to stay for some more time, and we established our company, we had some savings. (personal interview, October 7, 2016)

This quotation suggests that negative factors in the place of origin prevailed in decision to remain in Hungary, instead to return to a home country, as initially planned. Other (post-)Soviet families, which happened to work in Hungary at the time of the collapse of the Eastern bloc and socialist system in general, found themselves in a similar situation. Therefore, similar reasons motivated them to stay in Hungary.

My parents worked as representatives of a Soviet enterprise specializing on traveling tours in the former Eastern bloc. When the Soviet Union collapsed, Russia, where we come from, experienced a very hard times both economically and socially. Thus, my parents stayed here, and decided to continue their work in tourism. As a result they registered a company and they continued to work. I also worked with them for some time. (personal communication, April 15, 2015) 
Simultaneously, according to the financial director of the Russian-language newspaper Russian Courier, news received from friends and relatives from Russia was not simply warning, but shocking.

My father came to Hungary as a representative of APN [Agency of Political News, Soviet news agency] for three years. Then it was extended, but the Soviet Union collapsed soon after, and my parents established a Russian-language newspaper, and they decided to stay in Hungary. It was scary to go back to Russia, [...] because... some of their friends were killed [...] It was also not good environment for the kids, me and my brother were small at the time. (personal interview, October 4, 2016)

This quotation reveals the negative factors at home country, in this case Russia, that prompted these former Soviet citizens to stay in Hungary and become entrepreneurs. It also reveals that these factors were combined with personal reasons. Thus, while the experiences of these immigrant entrepreneurs differ in details, there are several important common features that influenced their decisions to become entrepreneurs. First, they came to Hungary at the time when the Socialist bloc and Soviet Union still existed. Second, a reason for coming to Hungary was either to study or to represent the Soviet companies for relatively short periods. As a consequence, none of them considered Hungary as the place of the permanent settlement. Third, due to the collapse of the Soviet Union and the Socialist bloc, they lost not only temporary positions in Hungary, but also a possibility to find jobs in their countries of origin. Last, but not least, these immigrants already spoke Hungarian at the time and developed social networks with the locals.

At the same time, their newly established companies required remaining in close ties with countries of origin, but also with the Russian-speaking diaspora in Hungary. As a result, many of them organized small businesses in similar branches, in which they used to work before.

As we had networks, we were bringing many technical spare parts, motors from

Russia to Hungary. As a result,... we earned much more money by doing our own business, than we could earn working for the salary. (Russian owner of a trade company, personal interview, October 7, 2016)

As this quotation suggests, entrepreneurship proved not only to be based on existing networks and work experiences, but sometimes also more profitable livelihood activity than positions of representatives of Soviet companies in Hungary. 


\section{2. "New Russian occupiers" and "beloved Russians": post-Soviet immigrant entrepreneurship in Hungary in the 1990s}

In contrast to the above analysed group of Soviet immigrant entrepreneurs, whose permanent migration and entrepreneurship was unplanned, subsequential post-Soviet migration to Hungary brought very diverse groups of people and took very different forms. According to a former interpreter of the Hungarian trade representative office in Russia,

[...] many emerging business and criminal post-Soviet groups came to Hungary with a primary goal to provide their families with "safe havens" and for money-laundering purposes. By the end of 1990s most of these criminal groups left Hungary and moved either to Western Europe or to Czech Republic and Slovakia in search for more business opportunities and better attitudes towards Russians. (personal interview, April 18, 2016)

This quotation suggests that initially positive factors related to Hungary as a place of destination were combined with personal factors, and then followed by the combination of negative factors in both home country and in Hungary as the first place of destination with positive factors in neighbouring countries of Hungary as the next place of destination. In this sense, Hungary happened to be a country of transit migration (Düvell, Molodikova and Collyer, 2014). Transcarpathian Hungarians represent a relatively large group among these post-Soviet migrants; however, entrepreneurs are relatively rare among them. As Antal's experience suggests, the networks with post-Soviet republics and the knowledge of Russian language served only as the basis to start his own small business as a used cars and spare car parts trader.

I came to Hungary right after the collapse of the Soviet Union as there was no visa regime. I am ethnic Hungarian, and Hungarian is my native language, but I learned Russian in the school, so I am fluent in it, too. [...] I started as trader of Lada cars and their spare parts, as at that time Lada was still very popular car here. [...] The business went well, but in the 2000s it faded, because western European cars became financially accessible and more attractive for Hungarians. Now me and my partners co-own this company, and we trade with used cars produced in the European Union, including Hungary. (trader of used cars, personal interview, July 8, 2016)

Simultaneously, other, non-Hungarian post-Soviet immigrants recognized a promising niche for entrepreneurship in the increasing flow of migrants from the former Soviet republics to Hungary. Similarly to the situations in high income economies, these flows generated the demand for 
more ethnic- or culture-based thereof, businesses. Largest among them is the food-products chain "Arbat".

In Hungary, which was a part of the Socialist bloc, there was no shop where one could buy Russian products. In the 1990s Hungary was flooded with new Russian migrants, who were eager to buy in Hungary traditional Russian foodproducts. We decided to fill in this gap, thus, early in 2000 we opened a retail shop titled "Arbat" after one of Moscow's oldest streets. The shop has specialized on the products typical for Russian and Soviet cuisine, so it soon became popular among the post-Soviet immigrants. We also tried to respond to the demand for Russian products on the part of Hungarian military elite and technical professionals, who studied in the Soviet Union. [...] As a result, we organized a chain of 11 "Arbat" shops all over Hungary. [...] Recently, we diversified our business by opening a fast-food restaurant, where we offer dishes from Russian, Ukrainian, Transcarpatian and Hungarian cuisine. (Natalia Gumenskaya, owner of "Arbat" chain, according to A. Popov, Russian Courier, February 19, 2012)

This quote suggest that "Arbat" started as a typical for traditional immigrants-receiving countries ethnic-based immigrants' business, and that it combined both negative and positive factors related to the country of origin with positive factors related to the country of destination. Unsurprisingly, according to the owner of "Arbat", and similarly to other post-Soviet owned businesses in Hungary, most frequently employees of "Arbat" are also immigrants from Russia, Ukraine and Belarus (according to A. Popov, Russian Courier, February 19, 2012). Simultaneously, in contrast to "ethnic enclave" thesis about the immigrant entrepreneurship, at least the owners of "Arbat" have not imported traditional Russian food-products from Russia or other post-Soviet republic.

The products that we trade with are predominantly made and imported from

Germany, because our main partners are there. We are exclusive distributors of many products in Hungary. We know producers personally and we always personally choose the products. (Natalia Gumenskaya, owner of "Arbat" chain, according to A. Popov, Russian Courier, February 19, 2012)

Moreover, according to an acquaintance of the owners of "Arbat", the producers of traditional food products in Germany are also representatives of post-Soviet diaspora in Germany (personal communication, January 31, 2013). On the contrary, according to the owner of another post-Soviet food chain in Hungary, "Smak", the "Siberia" company, which is a supplier of traditional Russian and post-Soviet food for "Smak", has not only German, 
but also Russian venture. Thus, some food products that are exported to the EU are produced in Russia, Ukraine and Belarus (personal communication, May 20, 2017). Hence, the later example speaks rather in favour of "ethnic enclave" thesis about immigrant entrepreneurship, which combines positive factors related to place of origin with positive factors in place of destination together prompting immigrant entrepreneurship.

On the opposite side of the spectrum of post-Soviet immigrant entrepreneurship in Hungary that emerged in the 1990s was a big business organized and conducted by the Russian citizens, Rakhimkulov family. Once known as the richest resident of Hungary, Megdet Rakhimkulov came to Hungary in 1992 as a representative of the Russian Gazprom, and, subsequentially, as the chairman of the Hungarian-Russian gas supply joint venture Panrusgaz. Simultaneously, Rakhimkulov registered Hungarian company, Kafijat Kft, which among Hungarian business circles was known for its participation in many diverse businesses related either directly or indirectly to Gazprom and other Russian state-owned companies. According to Weiner (2015), "a crown jewel" of the Rakhimkulov family assets was the General Banking and Trust - AEB, which was acquired by Gazprombank in 1996, and incorporated in Kafijat Kft in 1997. By 2004, 70\% of AEB operations were devoted to Gazprom and Gazprombank. Thus, Rakhimkulovs' business is a striking case of transformation of FDI into an entrepreneurial activity, based mostly on positive factors related to sending country combined with investing opportunities in the country of destination.

AEB's main clients have been Russian companies, involved in investment projects in Hungary. They included MDM Group, Zenit Ban, and Uralsib financial group. At the same time, Borsodchem, Mol and Magyar Telekom have been among the largest Hungarian corporate clients, and either AEB or Rahkimkulovs individually have been involved in various investment projects, or the attempts of such thereof, with the Russian companies investing in Hungary (Orban, 2008; Weiner, 2015). In 2007, when AEB was the sixth largest bank in Hungary by net income, it was taken over by the Hungarian subsidiary of the Austrian Volksbank (Weiner, 2015). Furthermore, in 2012, Hungarian subsidiary of Volksbank was acquired by the Russian state-owned Sberbank, which, as Weiner (2015) justly notices, traces continuity in close ties with Russian business. However, Rakhimkulovs seem to have very limited contacts with the rest of the post-Soviet diaspora in Hungary: "It has always been hard to get in touch with Rakhimkulovs, they have always been very closed people" (acquaintance of Ruslan Rakhimkulov, personal communication, September 24, 2016). 
Nevertheless, the same source suggests that Megdet Rakhimkulov's sons went further and diversified their entrepreneurial activities towards showbusiness: "Ruslan owns Magyar Virtuozok Ensemble. That is his ownership, there is a person employed to lead that Ensemble. He invited here Anastasia [popular singer], he organized a concert for her in Budapest" (acquaintance of Ruslan Rakhimkulov, personal communication, September 24, 2016). This quotation suggests that, similarly to immigrant entrepreneurs in Lesser Poland, as Brzozowski and Pedziwiatr (2016) observe, some postSoviet immigrant entrepreneurs in Hungary are quite part of the Hungarian mainstream economy, rather than ethnically or culturally based. Other businesses and investment projects with AEB and Kafijat Kft's involvement also included stakes in Hungarian largest tile manufacturer Zalakeramia, terrestrial broadcaster Antenna, Hungarian Gas Trade, Hungarian stateowned Electricity Company MVM and Hungarian Business Telecom.

On the other hand, due to close contacts with the Russian state-owned companies, many of these investments were followed by scandals because of usually non-transparent activities in Hungary. The most scandalous was the involvement of Irish registered Milford Holding company in deals concerning Hungarian petrochemical manufactories - Symbiotic TVK-Borsodchem-MOL ethylene pipelines - when Milford's representative in Hungary Megdet Rahkimkulov was accused to work on behalf of Gazprom's interests to return Hungary to the Russian zone of influence by using economic means (Orban, 2008; Weiner, 2015). Some observes even believe that these accusations were the main reason for Megdet Rakhimkulov's return to Russia in 2008; however, other knowledgeable informants argue that life cyclerelated motives influenced this Rakhimkulov's decision. This seems to be the only case when post-Soviet entrepreneurs in Hungary were accused to work on behalf of perverted Russian political interests. Overall Rakhimkulov's decision to return to Russia can be considered a combination of negative factors at the place of destination with personal factors. Nevertheless, according to other post-Soviet entrepreneurs in Hungary, the cases when they were discriminated by Hungarians for being Russians, or other postSoviets thereof, were very rare.

It was a great movement in the beginning of the 1990s, when everybody was celebrating liberation from the inflicted socialism. They did not want to keep in touch and to preserve any contacts with the Soviets. [...] But then, after the initial euphoria... they realized that it does not make sense to destroy these relations. [...] There was a wave of rich Russian tourists, who were coming to Hungary with an open soul and were giving a \$100 tips. And then Hungar- 
ian directors of hotels were coming to me kindly asking to bring them more and more Russian tourists. (Russian owner of tourism agency in Budapest; personal interview, October 19, 2016)

Overall, in contrast to all other post-Soviet immigrants, who came to Hungary prior to 2000s, the Rakhimkulovs' family business in Hungary has been built on their close connections with the large Russian, usually state-owned companies and investments of these companies in Hungary. It seems that Rakhimkulovs' connections with these companies were the reason why Rakhimkulovs were encountered with the negative reactions of the Hungarians.

\subsection{Newcomers: post-Soviet immigrants and their entrepreneurship in Hungary since mid-2000s}

By 2000s the international status of Hungary changed significantly. After economic and constitutional reforms, the country joined NATO. In 2003, similarly to other then EU candidate countries, Hungary abandoned visa-free regime with post-Soviet countries. This newly introduced visarequired regime can be classified under Lee's (1996) intervening obstacle group of factors influencing volumes of migration flows. In 2004, together with many other post-socialist countries, Hungary joined the EU. Educated and comparatively cheap labour force and existing industrial capacities attracted FDI from various multinational corporations (Bohle and Greskovits, 2012). At the same time, economic and social situation in Russia and other former Soviet republics also changed significantly between early and mid2000s. These changes generated new simultaneous migrations of the postSoviet entrepreneurs from Hungary to other European countries, and back to the former Soviet republics.

I know some of my compatriots, who have been here, but do not speak the language, and they do not feel comfortable here. [...] Unfortunately, there are many who spent some time here, and then they left, although their businesses were successful. Some moved further to Austria and Germany. They did not want to waste their time learning Hungarian, but decided to learn some easier language. (Russian owner of tourism agency in Budapest, personal interview, October 19, 2016)

This quotation suggests that in the eyes of some relatively successful post-Soviet entrepreneurs in Hungary, the country of destination turned into the country of transit towards more attractive destinations, due mostly to the lack of knowledge of the Hungarian language, which can be consid- 
ered a negative factor related to the place of destination, and the lack of the will to learn it thereof, which seems as entirely personal factor. Since mid-2000s, post-Soviet migration to Hungary seems to be rather rationally planned, and so seems the post-Soviet entrepreneurship in Hungary.

I came from Russia to study business in Hungary, and I realized that everything is considerably cheaper than in Moscow, including real estate. [...] I always wanted to start my own business in Russia, but it was either hard to get or earn an initial capital, or it was too complicated to organize any kind of company except offshore, which requires accounts abroad and other inconveniences. I realized that even with my yearly savings earned from my job in Moscow I can start some sort of a small business in Hungary, so I established a small real estate construction company. At the same time, this helped me to receive first temporary and then permanent residence in Hungary. (Russian owner of a small construction business, personal interview, September 15, 2014)

This quotation reveals that factors associated with the country of origin and perceived by the concrete person as negative, such as high price of starting a small business, were combined with positive factors in the place of destination, such as a relatively small initial investment needed to start a business in Hungary. The interviewee also noticed that his customers are mostly local Hungarians, and foreigners of Hungarian origin, who invest in Hungary. Thus, this particular business seems to be a part of mainstream Hungarian economy, rather than ethnic-based. Simultaneously, this quotation suggests that even relatively small portions of FDI serve not only as a basis for post-Soviet immigrant entrepreneurship in Hungary, but also, by default, as the basis to reside in Hungary.

Apart from being rationally planned, the new wave of post-Soviet entrepreneurship in Hungary also tends to be more diverse in entrepreneurial activities. For instance, Russian artist and shoe designer Anna Zaboeva decided to move to Budapest after her first visit to the Hungarian capital city. She recycles used clothes, carpets and accessories to produce new shoes (personal communication, December 3, 2010).

I came to Budapest first to present my short film at a film festival. I liked the city very much and decided to come again and to try myself here. [...] I applied for a post-graduate stipend at Moholy-Nagy University of Arts and got it, so I studied. It was hard because, at the time, I did not speak even English, not to mention Hungarian. [...] My diploma work, a pair of shoes were presented at an exhibition and sold by internet, they went to Italy. (according to Samarina, Daily Afisha.ru, February 23, 2009) 
Nonetheless, shoe production required more investments, so Zaboeva went to the job market. "I got a job at an international TV production of TVviktorinas. It was a well-paid position, I got a flat and a car, but there was nothing to be proud of in terms of creativity" (according to Samarina, Daily Afisha.ru, February 23, 2009). As a result, Zaboeva invested her savings into a shoe production: "I come from Siberia, therefore the name of my shoe shop is 'Siberia'”' (personal communication, December 3, 2010).

Thus, positive factors related to Hungary combined with professional interests that can also be regarded as personal factors attracted Zaboeva to establish her business in Budapest. Similarly to the previously analysed real estate construction business, Zaboeva's shoe production and trade main customers happened to be tourists visiting Budapest, and Hungarians (according to Samarina, Daily Afisha.ru, February 23, 2009).

At the same time, those post-Soviet entrepreneurs, who came to Hungary during the Soviet era, tend to diversify their entrepreneurial activities in response to a market demand.

Between 1995 and 2008 here was a "golden century" of tourism for everyone, who has specialized on Russia and the former Soviet Union. [...] Some of my clients, tourists, started to ask me whether it was possible to buy a flat here. So, I started to help them in finding an appropriate real estate. This is how I got in touch with Duna House [real estate agency] and their work. [...] Then one of my acquaintances told me that she wanted to sell her franchise... and I agreed with my partner from Moscow to buy it from her. So I started to develop the business about four years ago. [...] €100,000 in Moscow has not been a large amount. Here it is possible to buy a nice flat with that amount. [...] I always ask my clients what is their purpose of buying property here. Largest number of them simply wanted to invest their savings abroad, in order to have some "additional airport", but also to have an investment that is able to generate income. (Russian owner of tourism agency in Budapest, personal interview, October 19, 2016)

In this way investments in real estate seem to increasingly become a starting point for migration and entrepreneurship in Hungary for many residents of the former Soviet republics, but also a source for diversification of existing businesses for the already established post-Soviet entrepreneurs in Hungary. This quotation, therefore, suggests that positive factors in Hungary as the place of destination have attracted further wave of postSoviet immigrant entrepreneurs. 
Among those post-Soviet immigrant entrepreneurs, who settled in Hungary after the Soviet era, there are those who closed their previous businesses in trade, and established cultural foundations. The most well-known among them is "Alfavit", which serves to preserve Russian cultural heritage in Hungary.

Everything started from my son and from my daughter. We had to teach them Russian language. We simply decided to give Russian language to the kids. Two years we worked unofficially on the territory of the Russian Trade Representative Office. We were looking for an adequate form of work. [...] Step by step we understood that we have to establish a foundation. We became cultural-educational foundation. [...] We are financed only by the parents of the kids, who study at "Alfavit", and by some sponsors... There is an income tax ... it is possible to give $1 \%$ to a public organization. So the parents of the kids that study at "Alfavit" usually transfer this 1\% to us. (Rita Hasanova, owner of "Alfavit", personal interview, October 7, 2016)

Thus, apart from obvious personal factors, demand for such activity by the Russian-speaking community in Hungary prompted the establishment of "Alfavit". Similarly, the Russian theatre in Budapest is founded as a public organization for promotion of the Russian culture. Thus, according to its director, Zinaida Ziherman, it works on similar principles as "Alfavit".

Russians want to watch theatre in Russian. [...] The Embassy's Russian Cultural Center provides a venue for the theatre for free... We finance ourselves from the sales of tickets. Since we are an institution that promotes culture, we ask our visitors to support the theatre with $1 \%$ of their income tax. (telephone interview, May 20, 2016)

On the contrary, some of the first-wave post-Soviet entrepreneurs in Hungary used the EU common market and open borders policies to extend their business to other EU countries.

My parents moved to France four years ago and established there a newspaper. It is digest of all news in Russian, it is issued three times a year. Apart from that, they work on travel guide for France, southern coast, in Russian. (financial director of the Russian-language newspaper Russian Courier, personal interview, October 4, 2016)

Last but not least, since 2012 Hungary has incepted Hungarian Residency Bond program, according to which any non-EU (and non-European Economic Area) citizen can receive Hungarian, and thus the EU residence permit (Nagy, 2016), if s/he invested $€ 250,000$ minimum "in Special Hungarian Government Bonds that have a minimum 5-year maturity and are issued by 
the State through the Government Debt Management Agency" (Hungarian Ministry of Foreign Affairs, 2015). Nevertheless, at the moment of writing, there is yet no clear evidence on how many citizens of the former Soviet Union have used this scheme to receive residence permit. Still, it is not excluded that this investment-promoting policy will prompt further waves of post-Soviet and other immigrant entrepreneurs in Hungary. Overall, postSoviet entrepreneurship in Hungary has diversified over time from trade, tourism and Russian language media to retail chains, investments in real estate and fashion industries, but also to cultural entrepreneurship. With it immigrant entrepreneurship in Hungary gradually starts to resemble immigrant entrepreneurship in high income economies.

\section{CONCLUSIONS}

By tracing the post-Soviet immigrant entrepreneurship in Hungary over the last three decades and based on the analytical framework adapted from Lee (1966), this paper provides a nuanced insight in motives and patterns of migration between post-socialist countries and immigrant entrepreneurship in them, as well as several important contributions to the literature on migration and immigrant entrepreneurship. First, by addressing the question why people migrate from one to another post-socialist European country, this paper have looked at factors associated with both home countries, meaning republics of the former Soviet Union, and Hungary. Regarding the first wave of Soviets, who initially came to Hungary to work temporarily as representatives of Soviet companies, the main reason to stay in Hungary permanently was not as radical as war and political refugees from home countries analysed by Halilovich (2011), but rather general economic and social instability in countries of origin at the time of the collapse of the Soviet Union, as noticed by Wilson and Portes (1980) in their study of Cubans in Miami. This negative factor associated with a country of origin was combined with their existing knowledge of the local language and customs, both encompassing positive factors associated with the place of destination. Well-established networks with the local population also fell into two groups factors, namely first, positive factors associated with the country of destination, and second, personal factors. Another incentive to stay in Hungary permanently was a visa-free regime between Hungary and the former Soviet republics.

As a result, the entrepreneurship of this group of (post-)Soviet immigrants emerged in sectors of their previous employment, that is mainly in 
tourism, trade, and media. All these businesses have been based either on the close ties with home countries, such as tourist agencies and trade enterprises, or oriented on this Russian-speaking community, such as Russianlanguage media. Thus, while these findings to some extent coincide with "ethnic enclave" thesis regarding motivations for immigrant entrepreneurship proposed by Wilson and Portes (1980), and Light (1984), they also contribute to both migration and immigrant entrepreneurship with an extra set of motives, in addition to the previously proposed war refugees and political asylum by Halilovich (2011), revealing that after the collapse of the Socialist bloc early groups of immigrant entrepreneurs in post-socialist countries were formed in an entirely different way from those in traditional immigrant-receiving countries with high income economies.

Second conclusion derived from the analysis above is that the motives for later waves of post-Soviet immigrant entrepreneurs in Hungary fell mostly in the group of positive factors associated to the country of destination, i.e. the attractiveness of Hungary in terms of immigration because of visafree regime with post-Soviet republics until 2003, and as relatively fast and relatively successful in transforming from centrally-planned to free-market economy and from one-party regime to multi-party democracy. Similarly to the first-wave of (post-) Soviet immigrant entrepreneurs in Hungary, these positive factors associated with the host country were combined with negative factors associated with post-Soviet countries of origin, such as general dissatisfaction with economic situation and aforementioned search for better life standards. These motives combined with lack of intervening obstacles in a form of strict immigration laws prompted a significant number of post-Soviet migrants in Hungary. Consequently, based on these migrants' demand for traditional Soviet food, products, and Russian-language media and culture-related services, ethnic- and Russian culture-based post-Soviet immigrant entrepreneurship flourished in Hungary. This finding goes along the lines of the Orozco's (2008) argument, pointing out that demand from an ethnic community for certain ethnic products and/or services creates fertile ground and comparative advantage in comparison to the local population for immigrant entrepreneurship.

Third, simultaneously with this second wave of post-Soviet migrants, Hungary, as a former post-Socialist country with fast transforming economy and political system towards free market and democracy, also attracted FDI inflows by companies from the former Soviet republics as early as in 1993, most notably by the Russian energy companies. However, as data collected from the in-depth interviews with post-Soviet entrepreneurs and 
their Hungarian acquaintances suggests, these investments seemed to be motivated by the Russian state's political and post-Soviet migrants' individual money-laundering goals, but these FDI also served as an indirect source of immigrant entrepreneurship, most strikingly exemplified by Rakhimkulovs' family-owned Kafijat Kft. This finding partially answers another research question, namely, about the role of FDI in post-Soviet immigrant entrepreneurship in Hungary. Thus, this finding entirely confirms Lee's (1966: 53) proposition that "during periods of economic expansion $[\ldots]$ the contrast between the positive factors at origin and destination is [...] heightened, and the negative factors at origin seem more distressing". In the particular case of Russian companies' FDI in Hungary and Rakhimkulovs' business, which was built upon these FDI, it seems that they both were stimulated by the complex combination of negative factors associated with the country of origin, positive factors related to the country of destination, and personal factors. This finding coincides with Marchand and Siegel's (2014) argument that investment opportunities in host countries generate FDI, migrant inflows and immigrant entrepreneurship.

Nevertheless, partially due to the language barrier, and partially due to certain experiences of a discriminative nature, as the analysis above has demonstrated, some of post-Soviet immigrant entrepreneurs of the second wave decided to leave Hungary and to move either towards Western European countries with high income economies, or to other linguistically closer post-Socialist countries, notably Slovakia and the Czech Republic. In these cases Hungary turned into a country of transit migration, as analysed by Düvell, Molodikova and Collyer (2014). Similarly, other post-Soviet entrepreneurs of the second wave, who had not culturally integrated in Hungary, returned to their post-Soviet home countries and continued successful businesses there. This finding also confirms Lee's (1966: 55) argument that "[m]igrants become aware of opportunities at origin which were not previously exploited, or they may use contacts in the new area to set up business in an old".

Fourth, as the analysis above has demonstrated, motives that have prompted the most recent wave of post-Soviet migration to Hungary have combined all Lee's (1966) four groups of factors influencing migration. They have included relatively high prices of real estate and for starting bussiness in the country of origin compared to relatively low prices of real estate and for starting business in Hungary, which combines negative factors associated with the country of origin with relatively positive factors associated with the country of destination. These factors were combined 
with the introduction of visa regime between Hungary and the post-Soviet republics in 2003 prior to Hungary's EU accession in 2004, which created intervening obstacles in form of more strict immigration laws. All these factors together resulted, on the one hand, in small-scale FDI inflows that simultaneously served as a source for immigrant entrepreneurship and facilitated receiving of temporary and permanent residence permit for these immigrant entrepreneurs in Hungary. On the other hand, the most recent wave of post-Soviet immigration in Hungary resulted in diversification of post-Soviet immigrant entrepreneurship towards real estate construction, and shoe production and retail sectors, which are rather part of the mainstream economy than ethnic- or culturally-oriented businesses. This finding demonstrates that Rath's (2006) argument regarding immigrants from low-to-middle income countries, who invest their savings into small and medium businesses in high income traditional immigrant receiving countries in order to obtain residence permit partially holds for the third-wave post-Soviet immigrant entrepreneurs in Hungary. At the same time, this finding coincides with Brzozowski and Pedziwiatr's (2016) recent study of the immigrant entrepreneurs in Lesser Poland, demonstrating that their entrepreneurial activities constitute Polish mainstream economy, rather than any form of an ethnic enclave.

Finally, together with Brzozowski's and Pedziwiatr's (2016) argument about immigrant entrepreneurs in Lesser Poland, the findings of the current study of post-Soviet entrepreneurs in Hungary may serve as a profound foundation for further research of the effects of immigrant entrepreneurship on the economies of the post-socialist members of the EU. Thus, further research of entrepreneurship of other ethno-cultural diasporas in Hungary and in other post-socialist countries will allow for building a more general theory about migration and immigrant entrepreneurship in the post-socialist and other emerging markets.

Acknowledgements: The author wants to thank two anonymous reviewers for their valuable and useful comments and suggestions, Irina Molodikova from the Central European University for initial insights regarding post-Soviet diaspora in Hungary, and the members of the Central European University's Political Economy Research Group (PERG), especially Magdalena Ulceluse, for their comments on the first draft of the present research paper. Special thanks go to all surveyed and interviewed informants for sharing their experiences for the purpose of this study. The study was conducted with the support of Central European University's Global Teaching Fellowship. 


\section{REFERENCES}

Basch, L., Glick Schiller, N. and Szanton Blanc, C. (1994). Nations Unbound: Transnational Projects, Postcolonial Predicaments, and Deterritorialized Nation-States. New York: Routledge.

Bohle, D. and Greskovits, B. (2012). Capitalist Diversity on Europe's Periphery. Ithaca: Cornell University Press.

Brixy, U., Sternberg, R. and Vorderwülbecke, A. (2013). Start-Ups by Migrants. Hannover: Institute for Employment Research (IAB Brief Report, 25), http://doku.iab.de/ kurzber/2013/kb2513_englisch.pdf.

Brzozowski, J. and Pedziwiatr, K. (2016). Pushed to the Mainstream Market: The Case of Immigrant Entrepreneurs in Lesser Poland, in: L. Faltan (ed.). Cross-Border Migration and its Implications for the Central European Area. Bratislava: UNESCO MOST Programme, 178-198.

Byford, A. (2012). The Russian Diaspora in International Relations: "Compatriots" in Britain, Europe-Asia Studies, 64 (4): 715-735, doi: https://doi.org/10.1080/09668136.2 012.660764

Deakins, D., Ishaq, M., Smallbone, D., Whittam, G. and Wyper, J. (2007). Ethnic Minority Business in Scotland and the Role of Social Capital, International Small Business Journal: Researching Entrepreneurship, 25 (3): 307-326, doi: https://doi. org/10.1177/0266242607076530

Düvell, F., Molodikova, I. and Collyer, M. (eds). (2014). Transit migration in Europe. Amsterdam: Amsterdam University Press.

Entrepreneurship, in: Business Dictionary, WebFinance, Inc., http://www. businessdictionary.com/definition/entrepreneurship.html (4 May 2016).

Graham, L. (2013). Lonely Ideas. Can Russia Compete?. Cambridge - London: The MIT Press.

Halilovich, H. (2011). (Per)Forming “Trans-Local” Homes: Bosnian Diaspora in Australia, in: M. Valenta and S. Ramet (eds). The Bosnian Diaspora: Integration in Transnational Communities. Surrey - Burlington: Ashgate Publishing Limited, 63-81.

Hungarian Ministry of Foreign Affairs (2015). The Hungarian Investment Immigration Program. Budapest, http://www.mfa.gov.hu/NR/rdonlyres/1A5BB49E-75C4-429DA6E0- 0D3E753838BC/0/program_overview_EN.pdf (8 October 2016).

International Monetary Fund (2016). World Economic Outlook Database, April 2016, https://www.imf.org/external/pubs/ft/weo/2016/01/weodata/index.aspx (27 June 2017).

Janka, P., Černá, I., Prchalová, M. and Němcová, K. (2007). Migrants in the Czech Republic, https://www.zdravka-plzen.cz/sites/default/files/content/studie_migranti_final.pdf (12 October 2016).

Kugler, M. and Rapoport, H. (2011). Migration, FDI, and the Margins of Trade. Harvard: Harvard University (CID Working Paper, 222).

Kósa, D. (2015). Ukrainian migration in Hungary, http://www.szubjektiv.org/wpcontent/uploads/2016/02/migration-report-1.pdf (10 May 2016).

Lassalle, P., Hughes, M. and Helinska-Hughes, E. (2011). Polish Entrepreneurs in the Glasgow Area: Migratory and Business Strategies, Studia Migracyjne-Przeglad Polonijny, 37 (1): 129-152. 
Lee, E. S. (1966). A Theory of Migration, Demography, 3 (1): 47-57, doi: https://doi. org/10.2307/2060063

Light, I. (1984). Immigrant and ethnic enterprise in North America, Ethnic and Racial Studies, 7 (2): 195-216, doi: https://doi.org/10.1080/01419870.1984.9993441

Marchand, K. and Siegel, M.(2014). WorldMigration Report2015:Immigrant Entrepreneurship in Cities - Background Paper. International Organization for Migration.

Molodikova, I. (2014). Russian policy toward compatriots: diversities and contradictions of its implementation, Post-Soviet Diasporas: Identities, Linkages, and Transformation, Carleton, March 20-21, 2014.

Nagy, B. (2016). In Whose Interest? Shadow over the Hungarian Residency Bond Program. Geneva: Investment Migration Council - Transparency International, Hungary.

Orban, A. (2008). Power, Energy, and the New Russian Imperialism. Westport - London: Praeger Security International.

Orozco, M. (2008). Tasting Identity: Trends in Migrant Demand for Home-Country Goods. USAID.

Piore, M. J. (1979). Birds of Passage: Migrant Labor and Industrial Societies. Cambridge: Cambridge University Press.

Popov, A. [Попов, А.](2012). Ah Arbat, moi Arbat... [Ах Арбат, Мой Арбат...], Russian Courier online, February 19, 2012, http://www.kurier.hu/node/2184 (20 July 2016).

Portes, A. (1997). Globalization from Below: The Rise of Transnational Communities. Princeton: Princeton University (WPTC-98-01).

Rath, J. (2006). Entrepreneurship among Migrants and Returnees: Creating New Opportunities, International Symposium on International Migration and Development, Population Division, Department of Economic and Social Affairs, Turin, June 16, 2006.

Rath, J., Eurofound (2011). Promoting Ethnic Entrepreneurship in European Cities. Luxembourg: Publications Office of the European Union.

Samarina, X. [Самарина, K.] (2009). Litso. Anna Zaboeva [Лицо. Анна Забоева], Daily Afisha.ru, February 23, 2009, https://daily.afisha.ru/archive/gorod/archive/anna_ zaboeva/ (20 July 2016).

UN (2015). International Migration Report. New York.

Waldinger, R. (2009). Beyond Transnationalism: An Alternative Perspective on Immigrants' Homeland Connections, in: M. Rosenblum and D. Tichenor (eds). Oxford Handbook of the Politics of International Relations. New York: Oxford University Press, 74-102, doi: https://doi.org/10.1093/oxfordhb/9780195337228.013.0004

Weiner, C. (2015). Tracking Russian FDI in Hungary, in: A. Deák (ed.). East European Studies, 6. Budapest: Institute of World Economics, Research Centre for Economic and Regional Studies, Hungarian Academy of Sciences, 120-169.

Wilson, K. L., and Portes, A. (1980). Ethnic Enclaves: An Analysis of the Labor Market Experiences of Cubans in Miami, American Journal of Sociology, 86 (2): 295-319, doi: https://doi.org/10.1086/227240

Zhou, M. (2004). Revising Ethnic Entrepreneurship: Convergencies, Controversies, and Conceptual Advancements, International Migration Review, 38 (3): 1040-1074, doi: https://doi.org/10.1111/j.1747-7379.2004.tb00228.x 


\title{
Imigrantsko poduzetništvo u postsocijalističkim zemljama Europske Unije: motivi i obrasci poduzetništva postsovjetskih imigranata u Mađarskoj
}

\section{Sanja Tepavcevic}

\begin{abstract}
SAŽETAK
U radu se istražuje odnos između migracija, poduzetništva i izravnih stranih ulaganja s fokusom na poduzetničke aktivnosti postsovjetskih (i)migranata u Mađarskoj između 1991. i 2016. Postsovjetski migranti nalaze se u fokusu jer je između 1956. i 1989. Sovjetski Savez prisiljavao Mađarsku na ostanak u Socijalističkom bloku. Temeljeći se na anketama i dubinskim intervjuima, u radu se prikazuju značajne razlike u obrascima poduzetništva postsovjetskih imigrantskih poduzetnika u Mađarskoj koje većinom ovise o vremenu njihova dolaska u Mađarsku. Isto tako, motivi za pokretanje poduzetništva među prvim valom imigranata spajaju negativne faktore u bivšemu Sovjetskom Savezu s pozitivnim faktorima s kojima su se imigranti susreli u Mađarskoj, dok faktori koje većina tih imigranata u Mađarskoj smatra pozitivnima dominiraju među motivima kasnijih valova postsovjetske migracije i poduzetništva u toj zemlji. Ovaj rad također pokazuje da su od 2000. državljani bivših sovjetskih republika ostvarili mnogo relativno malih ulaganja u Mađarskoj. Neka od njih preobrazila su se u poduzetničke aktivnosti koje istodobno služe kao temelj imigracije u Mađarsku.
\end{abstract}

KLJUČNE RIJEČI: imigrantsko poduzetništvo, postsovjetski imigranti, Mađarska, izravna strana ulaganja, postsocijalističke zemlje Europske Unije 